\title{
35. DATA REPORT: GEOCHEMISTRY OF PLIOCENE AND MIOCENE CARBONATES FROM THE ERATOSTHENES SEAMOUNT (SITE 965) ${ }^{1}$
}

\author{
Michael E. Böttcher, ${ }^{2,4}$ Yossi Mart, ${ }^{3}$ and Hans-Jürgen Brumsack ${ }^{2}$
}

\section{INTRODUCTION}

Site 965 is located south of Cyprus on the fault-controlled upper slope of the Eratosthenes Seamount (Emeis, Robertson, Richter, et al., 1996). During drilling of Hole 965A, carbonate samples from different time intervals were recovered. In the present study, one early Pliocene and ten Miocene carbonate samples were analyzed for their mineralogy, major elements $(\mathrm{Ca}, \mathrm{Mg})$, trace elements $(\mathrm{Sr}, \mathrm{Mn}, \mathrm{Fe}$, $\left.\mathrm{P}_{2} \mathrm{O}_{5}, \mathrm{TiO}_{2}\right)$, and stable isotopes $\left({ }^{13} \mathrm{C},{ }^{18} \mathrm{O},{ }^{34} \mathrm{~S}\right)$. It is the purpose of this study to present initial results on the geochemical composition of these carbonates as a base for a future detailed investigation to estimate the paleoenvironment from the carbonate geochemistry.

\section{ANALYTICAL METHODS}

The carbonates were analyzed onboard ship by standard atomic absorption (AAS) methods following acid-digestion in hot $6 \mathrm{~N} \mathrm{HCl}$ for their $\mathrm{Ca}, \mathrm{Mg}, \mathrm{Sr}, \mathrm{Mn}$, and $\mathrm{Fe}$ concentrations (accuracy better than $\pm 5 \%$ ), and on land by X-ray fluorescence (XRF) spectroscopy (Philips $\mathrm{PW} 2400 \mathrm{X}$-ray spectrometer) for $\mathrm{Ca}, \mathrm{Mg}, \mathrm{Sr}, \mathrm{TiO}_{2}$, and $\mathrm{P}_{2} \mathrm{O}_{5}$. $\mathrm{Re}-$ sults for $\mathrm{SiO}_{2}$ and $\mathrm{Al}_{2} \mathrm{O}_{3}$ were below the detection limit of XRF.

The mineralogical phase composition was analyzed by Fourier Transform infrared spectroscopy (Mattson 3000 type FTIR spectrometer; $\mathrm{KBr}$ pellet technique) at the Laboratory for Raw and Residual Mineral Materials, Heiligenstadt and by X-ray powder diffraction (Philips XRD-goniometer and Ni-filtered $\mathrm{CuK} \alpha$-radiation) at the Senckenberg Institute, Wilhelmshaven. Mg contents of selected magnesian calcites and calcian dolomites were estimated from variation in the wave numbers of the internal modes of the carbonate ion group with composition in the binary system $\mathrm{CaCO}_{3}-\mathrm{MgCO}_{3}$ (Böttcher and Gehlken, 1995; Böttcher et al., 1997). The relative amounts of calcite and dolomite were estimated from variation in the heights of the $\mathrm{d}(104)$ peaks in the X-ray patterns (Tennant and Berger, 1957). Degree of order in the dolomite lattice was estimated from the ratio of the peaks near $2 \Theta \approx 35.3^{\circ}$ and $37.3^{\circ}$ (Füchtbauer and Goldschmidt, 1955).

Stable carbon and oxygen isotope ratios of the calcite and dolomite fractions were measured on $\mathrm{CO}_{2}$ liberated from the carbonates by the reaction with anhydrous phosphoric acid using the sealed vessel method (Böttcher, 1996). The procedure to separate $\mathrm{CO}_{2}$ from the calcite and dolomite fraction is based on the different reaction rates of calcite and dolomite with phosphoric acid (Walters et al., 1972; Al-Aasm et al., 1990). The bulk samples were reacted for about 60

${ }^{1}$ Robertson, A.H.F., Emeis, K.-C., Richter, C., and Camerlenghi, A. (Eds.), 1998. Proc. ODP, Sci. Results, 160: College Station, TX (Ocean Drilling Program).

${ }^{2}$ Institute of Chemistry and Biology of the Marine Environment (ICBM), Carl von Ossietzky University, P.O. Box 2503, D-26111 Oldenburg, Federal Republic of Germany.

${ }^{3}$ Leon Recanati Center for Marine Studies, University of Haifa, Mt. Carmel, Haifa 31905, Israel.

${ }^{4}$ Present address: Department of Biogeochemistry, Max-Planck-Institute for Marine Microbiology, Celsinsstr. 1, D-28359 Bremen, Federal Republic of Germany.

mboettch@mpi-bremen.de min at $23^{\circ} \mathrm{C}$ and the evolved $\mathrm{CO}_{2}$ was assumed to be mainly derived from calcite. After the isotope measurement, the gas was pumped away on a vacuum line and the residual solid, which was assumed to be mainly dolomite, was allowed to react with phosphoric acid at $50^{\circ} \mathrm{C}$ for about $14 \mathrm{~h}$. The assumption of the separation of calcite from dolomite was confirmed by comparing the $\mathrm{CO}_{2}$ mass spectrometric inlet signals (mass 44) of the samples with those of known amounts of synthetic calcite. Measurements of isotope ratios were carried out on a Finnigan MAT 251 triple collector gas mass spectrometer at the Geochemical Institute of Göttingen University, considering the usual isobaric interferences following the procedure of Craig (1957). The oxygen isotope ratio of the $\mathrm{CO}_{2}$ gas was evaluated using the acidfractionation factors of Böttcher (1996) and Rosenbaum and Sheppard (1986) for calcite $(\alpha=1.01034)$ and dolomite $(\alpha=1.01081)$, respectively. Isotope ratios are given in the $\delta$-notation with respect to the Peedee Belemnite (PDB) standard. The reproducibility was generally better than $\pm 0.2 \%$.

For the determination of structurally bonded sulfate, selected carbonates were washed in distilled water and dissolved in $6 \mathrm{M} \mathrm{HCl}$. The dissolved sulfate was precipitated as $\mathrm{BaSO}_{4}$ by the addition of barium chloride and separated from the supernatant by centrifugation. The solid was washed and dried, and the sulfur isotopic composition was measured by combustion-isotope ratio monitoring-mass spectrometry (C-irmMS; Böttcher et al., Chap. 29, this volume). $\mathrm{BaSO}_{4}$ was combusted in an elemental analyzer (Carlo Erba EA 1108) connected to a Finnigan MAT 252 gas mass spectrometer via a Finnigan MAT Conflo II split interface. The liberated $\mathrm{SO}_{2}$ gas was transported to the mass spectrometer in a continuous stream of $\mathrm{He}$ (5.0 grade). Sulfur isotope ratios are related to the Vienna-Canyon Diablo troilite (VCDT) standard. The reproducibility was better than $\pm 0.3 \%$.

Thermodynamic saturation states of pore waters recovered from the upper part of Site 965 were calculated with the computer program Solmineq.88/PC Shell (Kharaka et al., 1988; Wiwchar et al., 1988). Deviation from equilibrium is given as saturation index, according to

$$
\mathrm{SI}=\log \left(\mathrm{IAP} / \mathrm{K}_{\mathrm{sp}}\right),
$$

where IAP is the measured ion activity product, and $\mathrm{K}_{\mathrm{sp}}$ is the theoretical solubility product. Solubility products at $25^{\circ} \mathrm{C}$ were taken from Plummer and Busenberg (1982) and the Solmineq database (Kharaka et al., 1988).

\section{RESULTS AND DISCUSSION Carbonate Mineralogy}

Except for traces of quartz, no mineral phases other than magnesian calcite or calcian dolomite were found by FTIR spectroscopy and X-ray powder diffraction, in accordance with bulk sample chemistry (Table 1). No aragonite was observed in any of the samples. Whereas the Pliocene carbonate sample consists only of low-magnesian calcite (LMC), dolomite was found in varying proportions in all Miocene carbonates (Table 2). The relative amounts of calcite and dolomite as determined by XRD and calculated from the bulk chem- 
Table 1. Major and trace element data for carbonates from Site 965.

\begin{tabular}{|c|c|c|c|c|c|c|c|c|c|c|c|}
\hline $\begin{array}{l}\text { Core, section, } \\
\text { interval }(\mathrm{cm})\end{array}$ & $\begin{array}{l}\text { Depth } \\
\text { (mbsf) }\end{array}$ & $\begin{array}{c}\mathrm{Mg}, \text { AAS } \\
(\mathrm{wt} \%)\end{array}$ & $\begin{array}{c}\mathrm{Mg}, \mathrm{XRF} \\
(\mathrm{wt} \%)\end{array}$ & $\begin{array}{c}\mathrm{Ca}, \mathrm{AAS} \\
(\mathrm{wt} \%)\end{array}$ & $\begin{array}{l}\mathrm{Ca}, \mathrm{XRF} \\
(\mathrm{wt} \%)\end{array}$ & $\begin{array}{l}\mathrm{Sr}, \mathrm{AAS} \\
(\mathrm{mg} / \mathrm{kg})\end{array}$ & $\begin{array}{l}\mathrm{Sr}, \mathrm{XRF} \\
(\mathrm{mg} / \mathrm{kg})\end{array}$ & $\begin{array}{c}\mathrm{Mn} \\
(\mathrm{mg} / \mathrm{kg})\end{array}$ & $\begin{array}{c}\mathrm{Fe} \\
(\mathrm{mg} / \mathrm{kg})\end{array}$ & $\begin{array}{l}\mathrm{P}_{2} \mathrm{O}_{5} \\
\text { (wt\%) }\end{array}$ & $\begin{array}{c}\mathrm{TiO}_{2} \\
(\mathrm{wt} \%)\end{array}$ \\
\hline \multicolumn{12}{|l|}{$160-965 \mathrm{~A}-$} \\
\hline $4 \mathrm{H}-3,98-100$ & 23.79 & 0.4 & 0.5 & 40.1 & 38.4 & 390 & 405 & 78 & 1100 & 0.093 & 0.028 \\
\hline $17 X-1,1-3$ & 144.72 & 1.7 & 1.8 & 38.4 & 37.2 & 615 & 617 & 50 & 170 & 0.025 & 0.011 \\
\hline $19 X-1,1-3$ & 163.92 & 5.9 & 5.9 & 32.9 & 31.6 & 650 & 659 & 42 & 150 & 0.035 & 0.009 \\
\hline $19 \mathrm{X}-1,49-51$ & 164.40 & 3.5 & 3.6 & 36.5 & 35.0 & 755 & 733 & 31 & 120 & 0.030 & 0.009 \\
\hline $21 X-1,5-7$ & 183.16 & 11.1 & 11.2 & 25.0 & 24.4 & 320 & 334 & 38 & 190 & 0.058 & 0.011 \\
\hline $23 \mathrm{X}-1,28-30$ & 202.49 & 11.3 & 11.3 & 24.7 & 24.2 & 290 & 297 & 33 & 140 & 0.056 & 0.007 \\
\hline $24 \mathrm{X}-1,80-82$ & 212.71 & 5.2 & 5.2 & 33.6 & 32.7 & 530 & 530 & 42 & 140 & 0.048 & 0.009 \\
\hline $25 X-1,57-58$ & 222.08 & 11.5 & 11.2 & 25.3 & 24.1 & 260 & 268 & 47 & 280 & 0.058 & 0.009 \\
\hline $26 \mathrm{X}-1,57-59$ & 231.68 & 1.5 & 1.5 & 38.8 & 37.9 & 425 & 440 & 31 & 100 & 0.047 & 0.012 \\
\hline $26 \mathrm{X}-1,115-117$ & 232.26 & 6.5 & 6.6 & 32.2 & 30.8 & 370 & 380 & 34 & 80 & 0.045 & 0.008 \\
\hline $27 X-1,45-47$ & 241.26 & 6.9 & 7.0 & 31.4 & 30.5 & 410 & 427 & 47 & 60 & 0.042 & 0.008 \\
\hline
\end{tabular}

Note: $\mathrm{AAS}=$ atomic absorption spectroscopy $\mathrm{XRF}=\mathrm{X}$-ray fluorescence.

Table 2. Amounts of dolomite obtained from XRD measurements and chemical analysis (Table 1), and Mg contents of selected calcite and dolomite samples obtained from FTIR spectroscopy.

\begin{tabular}{lcccc}
\hline $\begin{array}{c}\text { Core, section, } \\
\text { interval }(\mathrm{cm})\end{array}$ & $\begin{array}{c}\text { Dolomite } \\
\text { XRD } \\
(\mathrm{wt} \%)\end{array}$ & $\begin{array}{c}\text { Dolomite } \\
\mathrm{AAS} \\
(\mathrm{wt} \%)\end{array}$ & $\begin{array}{c}\text { Calcite } \\
\mathrm{MgCO}_{3} \\
(\mathrm{~mol} \%)\end{array}$ & $\begin{array}{c}\text { Dolomite } \\
\mathrm{MgCO}_{3} \\
(\mathrm{~mol} \%)\end{array}$ \\
\hline $\begin{array}{l}4 \mathrm{H}-3,98-100 \\
17 \mathrm{X}-1,1-3\end{array}$ & 0 & 0 & 2.7 & - \\
$19 \mathrm{X}-1,1-3$ & 20 & 14 & - & - \\
19X-1, 49-51 & 20 & 44 & - & - \\
$21 \mathrm{X}-1,5-7$ & $>90$ & 87 & - & 46 \\
$23 \mathrm{X}-1,28-30$ & $>90$ & 86 & - & - \\
$24 \mathrm{X}-1,80-82$ & 40 & 40 & - & - \\
$25 \mathrm{X}-1,57-58$ & $>90$ & 85 & - & - \\
$26 \mathrm{X}-1,57-59$ & 10 & 11 & 4.4 & - \\
$26 \mathrm{X}-1,115-117$ & 50 & 50 & - & - \\
\hline
\end{tabular}

Notes: FTIR $=$ Fourier Transform infrared spectroscopy. XRD = X-ray diffraction; AAS $=$ atomic absorption spectroscopy. $-=$ not determined.

ical data agree well and vary between $\sim 10$ and $90 \mathrm{wt} \%$ dolomite (Table 2). No consistent variation as a function of depth was observed (Fig. 1). FTIR spectroscopy indicates that only LMC or calcium-rich dolomite are present. Although, the XRD pattern of dolomite generally shows the ordering reflex near $2 \Theta \approx 35.2^{\circ}$, the excess calcium in the dolomite and the estimated degree of ordering in the dolomite lattice of dolomite-rich samples ( $>40 \%$ dolomite) indicate low temperatures during dolomite formation (Füchtbauer \& Goldschmidt, 1955).

\section{Trace elements}

The Fe and Mn contents of all carbonate samples are generally higher than estimated by Veizer (1983) for calcite and dolomite compositions in equilibrium with modern seawater. No relation is observed between the Mn and Fe contents of Miocene bulk carbonates with depth or calcite/dolomite ratios (Table 1). This is a clear indication for an intense recrystallization of the carbonates, even the calcite fraction, with diagenetic fluids that were enriched in $\mathrm{Mn}$ and Fe compared to normal seawater because of the reductive dissolution of $(\mathrm{Mn}$, $\mathrm{Fe}$ )-oxyhydroxides. The relatively high Fe content of the Pliocene LMC is probably caused by the presence of clay minerals (Emeis, Robertson, Richter, et al., 1996) or iron oxyhydroxide traces.

$\mathrm{P}_{2} \mathrm{O}_{5}$ is highest in the Pliocene sample, and a possible positive relation exists between $\mathrm{P}_{2} \mathrm{O}_{5}$ and the dolomite contents of the Miocene samples (Table 1), suggesting that some fixation of $\mathrm{P}_{2} \mathrm{O}_{5}$ occurred upon dolomitization.

Significant variations of the $\mathrm{Sr}$ contents are observed as a function of depth and dolomite content (Fig. 1). The good agreement between the AAS and XRF analyses (Fig. 2) confirms that $\mathrm{Sr}$, as well as $\mathrm{Ca}$ and $\mathrm{Mg}$, are bound in the carbonate matrix. From a plot of the Sr vs. dolomite contents of Miocene carbonates, it is inferred that the $\mathrm{Sr}$ content decreases with increasing amounts of dolomite (Fig. 3). From the limiting lines, a range of $\mathrm{Sr}$ contents for the LMC fractions between 400 and $1000 \mathrm{ppm}$ is extrapolated, and a decrease of $\mathrm{Sr}$ in the LMC fraction with depth may be estimate1d (Fig. 3). This Sr range indicates formation under essentially open-system conditions with respect to seawater-like solutions, considering the partition coefficient derived by Katz et al. (1972) from aragonite recrystallization experiments. The dolomite-rich samples plot close to each other (Fig. 3 ), and an average Sr content of 200-300 ppm is estimated for the pure dolomite fraction. Based on the model of Kretz (1982), it is therefore suggested that the fluids from which the Miocene LMC and dolomites were deposited had similar Sr:Ca ratios, although smaller variations are estimated for the dolomite-forming fluids. A lower $\mathrm{Sr}: \mathrm{Ca}$ ratio is in agreement with the supposed origin under the paleosol conditions of the Pliocene LMC.

\section{Stable Carbon, Oxygen, and Sulfur Isotopes}

The stable isotope compositions of the different carbonate phases differ significantly from each other (Fig. 4; Table 3). As expected from thermodynamic considerations (Golyshev et al., 1981; Zheng, 1997), the dolomites are generally enriched in ${ }^{13} \mathrm{C}$ and ${ }^{18} \mathrm{O}$ with respect to LMCs. In addition, the Pliocene LMC is additionally depleted in the heavy isotopes with respect to Miocene calcites. The results are used to estimate the compositions of the carbonate-forming fluids, assuming isotopic equilibrium.

The carbon isotopic composition of dissolved inorganic carbon $\left(\mathrm{DIC} \cong \mathrm{HCO}_{3-}\right)$ in equilibrium $\left(25^{\circ} \mathrm{C}\right)$ with the Pliocene and Miocene calcites and dolomites was calculated with the fractionation factors for calcite- $\mathrm{HCO}_{3-}$ and calcite-dolomite derived by Romanek et al. (1992) and Golyshev et al. (1981), respectively. The calculated $\delta^{13} \mathrm{C}(\mathrm{DIC})$ values for the Miocene calcites are typical for present-day seawater in equilibrium with the Earth's atmosphere. The results for the dolomites, however, are slightly shifted to lower values, probably due to an enhanced contribution of inorganic carbon derived from decomposed organic matter. In agreement with its supposed formation under paleosol conditions, the lightest carbon isotopic composition $\left(\delta^{13} \mathrm{C} \approx-2 \% o\right)$ is obtained for DIC in equilibrium with the Pliocene LMC (Fig. 1).

For oxygen isotope fractionation between dolomite and water, the theoretical (Zheng, 1997) and experimentally observed (Matthews and Katz, 1977) degrees of oxygen isotope fractionation agree within $0.4 \%$ (Fig. 1). A much larger difference, however, is observed for the calcite- $\mathrm{H}_{2} \mathrm{O}$ system (Zheng, 1997; O'Neil et al., 1969). Within the calculation uncertainty, the $\delta^{18} \mathrm{O}$ for $\mathrm{H}_{2} \mathrm{O}$ calculated from the oxygen isotopic composition of all carbonates yields an average $\delta^{18} \mathrm{O}$ value of about $+1 \%$. All data cover the isotope value for present-day Med- 

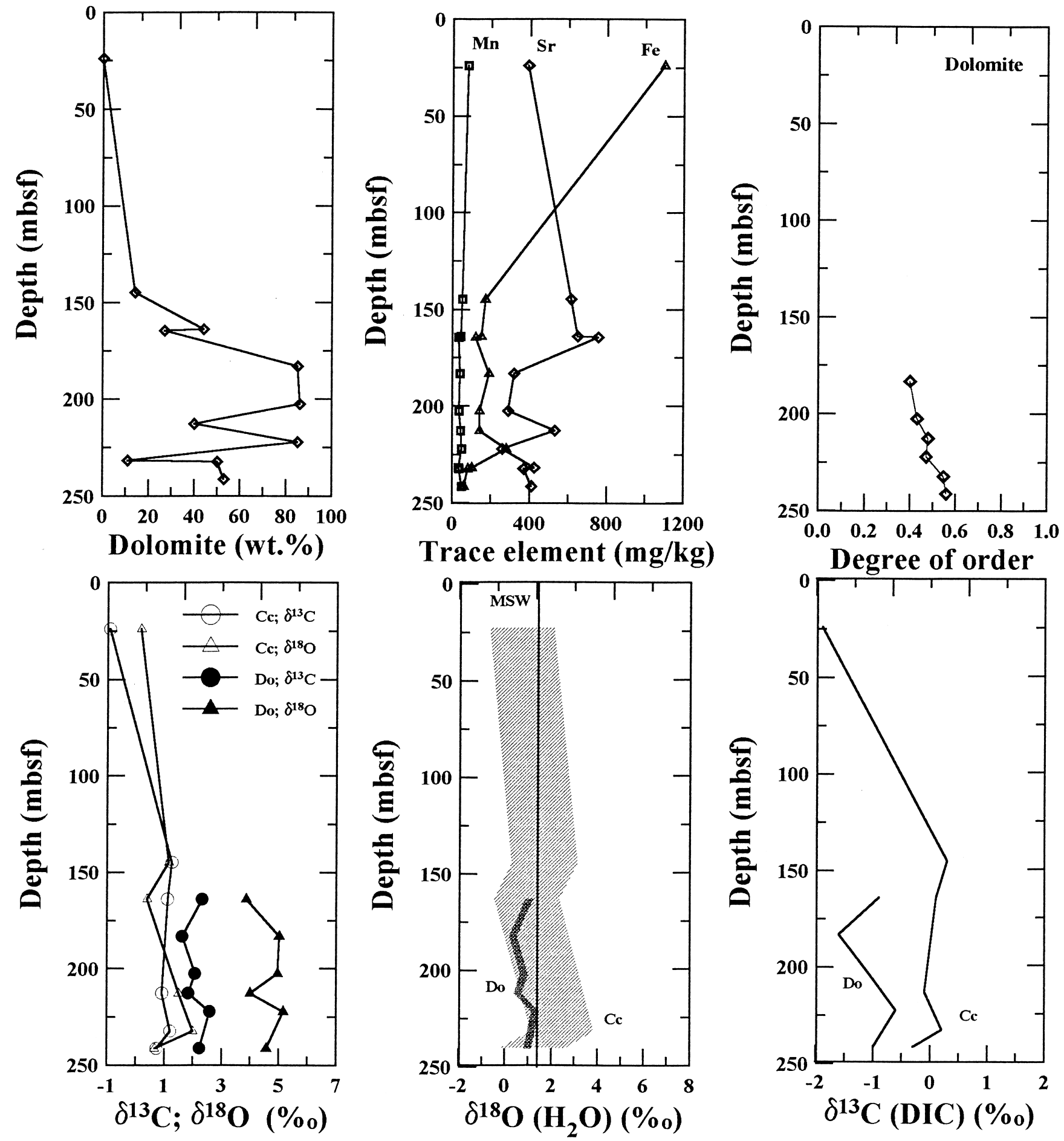

Figure 1. Variation of trace element and relative dolomite amounts of bulk carbonate samples, stable isotope data of calcite and dolomite, calculated equilibrium compositions of $\mathrm{H}_{2} \mathrm{O}$ and DIC (see text), and degree of order of selected dolomite samples. $\mathrm{Cc}=$ calcite; Do = dolomite.

iterranean seawater (Fig. 1; Stenni and Longinelli, 1990). Therefore, there is no clear indication for the contribution of meteoric water during carbonate formation and subsequent recrystallization reactions.

The $\delta^{34} \mathrm{~S}$ values of sulfate liberated from selected dolomite-rich Miocene samples $\left(\delta^{34} \mathrm{~S}=+23.7 \pm 0.1 \%\right.$ o $)$ are higher than the presentday Mediterranean seawater sulfate $\left(\delta^{34} \mathrm{~S} \approx+21 \%\right.$; de Lange et al.,
1990; Böttcher et al., Chap. X, this volume [Ms002]) and pore waters at Site 965 at 6.78 and 16.28 mbsf (Table 4). Assuming no isotope fractionation upon sulfate incorporation into the carbonate lattice (Burdett et al., 1989), the contribution of slightly heavier seawater sulfate upon dolomitization is probably caused by a decrease in the $\delta^{34} \mathrm{~S}$ value of seawater sulfate over the past 5 m.y. (Claypool et al., 


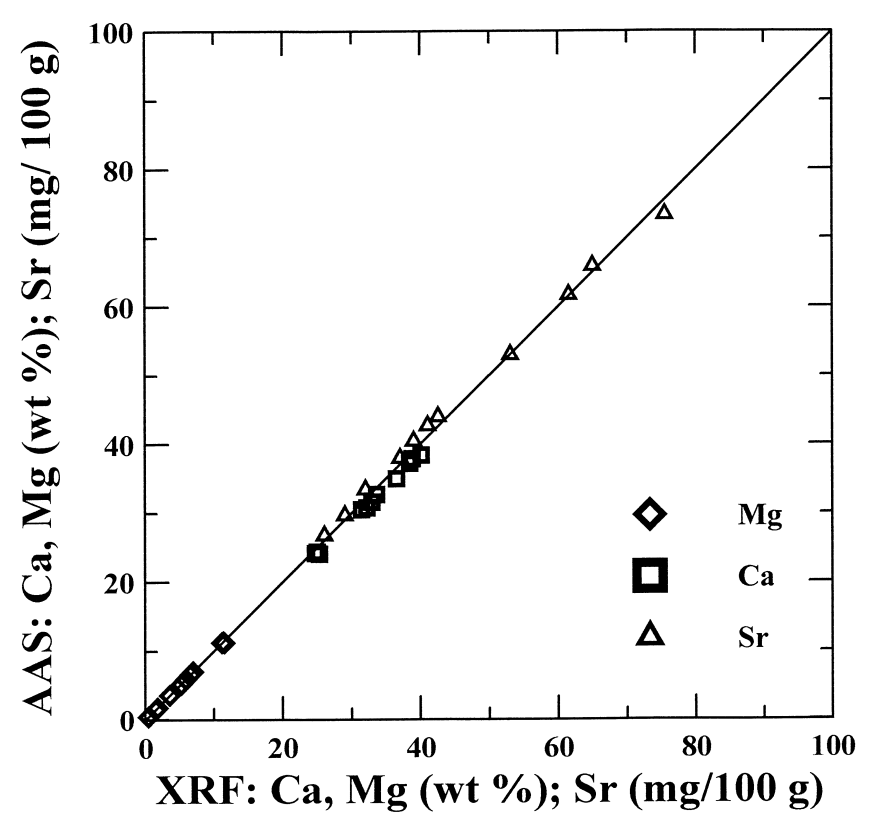

Figure 2. Comparison of analytical results obtained by XRF and AAS for Mg, $\mathrm{Ca}$, and $\mathrm{Sr}$ on bulk carbonate samples.

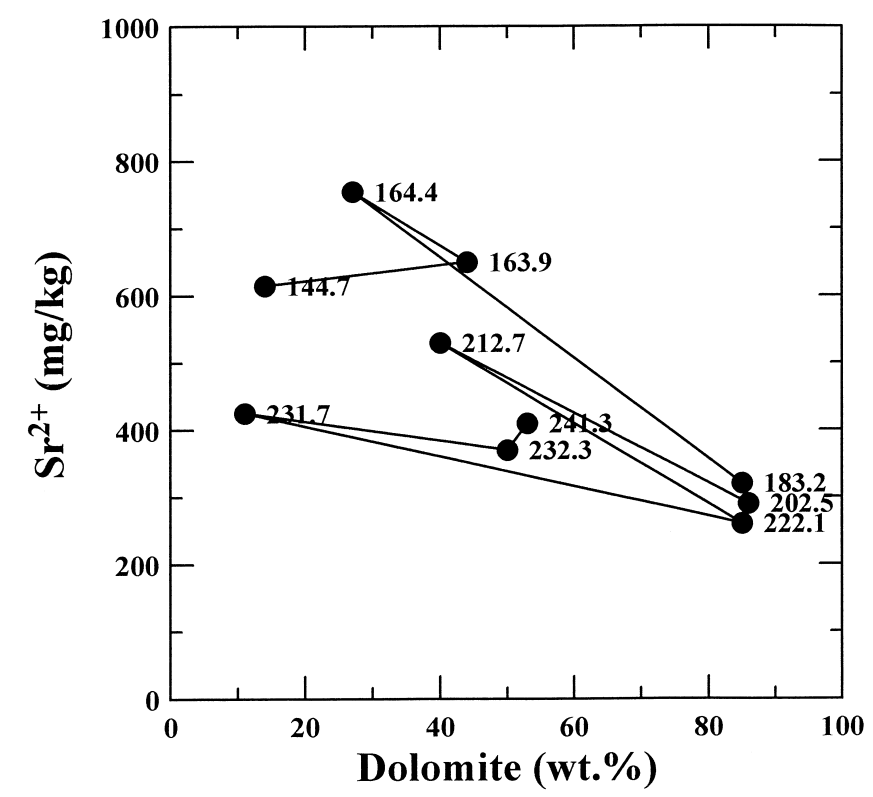

Figure 3. Variation of $\mathrm{Sr}$ contents of bulk carbonate samples with the amount of dolomite. Numbers indicate sampling depth in meters below seafloor.

1980; Burdett et al., 1989). For the late Miocene, for instance, Burdett et al. (1989) report $\delta^{34} \mathrm{~S}$ values up to $+23.8 \%$. However, an influence of solutions that had undergone slight sulfate reduction cannot be completely ruled out.

The compositions of the recovered pore waters from Site 965 are compiled in Table 4 together with their saturation indices with respect to calcite and disordered and ordered dolomite. The solutions are slightly subsaturated with respect to calcite and disordered dolomite, but significantly supersaturated with respect to ordered dolomite. From a thermodynamic point of view, the solutions should be

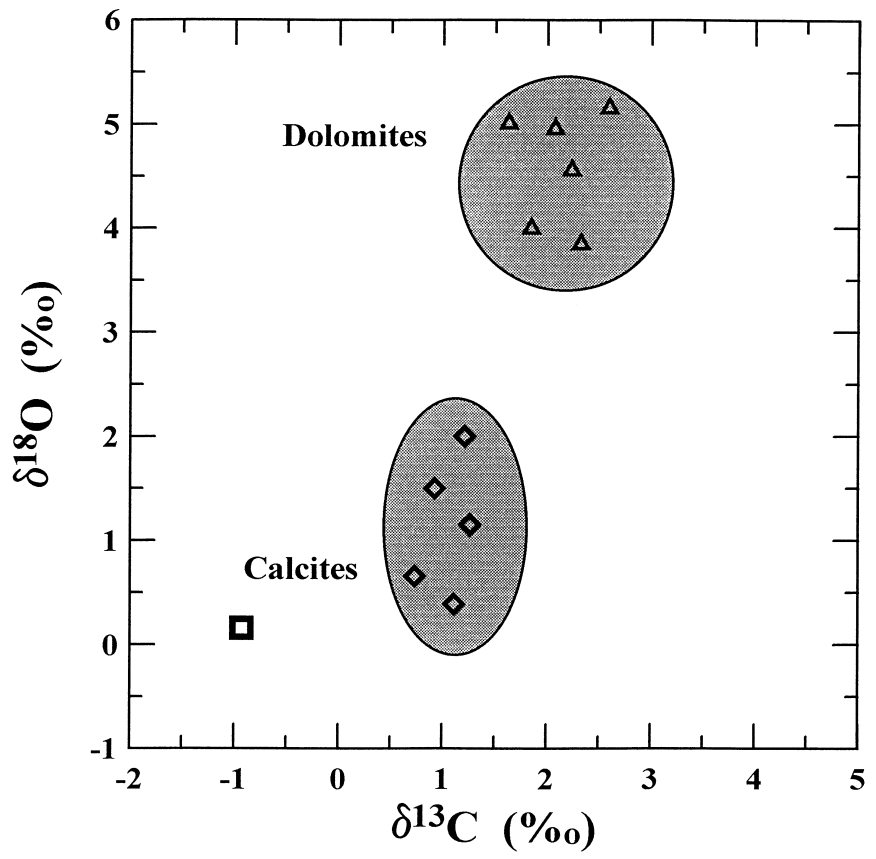

Figure 4. Scatter plot of carbon and oxygen isotope compositions of the dolomite and calcite fractions.

able to dolomitize calcium carbonate. However, the interstitial waters are only slightly concentrated with respect to normal seawater (Table 4). From a comparison of these data with modern dolomite-forming environments (Morse and Mackenzie, 1990), it is clear that the sampled pore waters were not responsible for the dolomitization processes resulting in the observed Miocene carbonate assemblages.

\section{ACKNOWLEDGMENTS}

We thank the shipboard scientific party and technical staff for their help in obtaining samples for geochemical analysis. We are also grateful to Drs. P.-L. Gehlken and M. Tintelnot for the FTIR and XRD measurements, respectively. We further acknowledge the comments of Prof. Dr. Y.-F. Zheng and an anonymous reviewer. This work was supported by German Science Foundation during DFGSPP Ocean Drilling Project.

\section{REFERENCES}

Al-Aasm, I.S., Taylor, B.E., and South, B., 1990. Stable isotope analysis of multiple carbonate samples using selective acid extraction. Chem. Geol., $80: 119-125$

Böttcher, M.E., 1996. ${ }^{18} \mathrm{O} /{ }^{16} \mathrm{O}$ and ${ }^{13} \mathrm{C} /{ }^{12} \mathrm{C}$ fractionation during the reaction of carbonates with phosphoric acid: effects of cationic substitution and reaction temperature. Isotopes Environ. Health Stud., 32:299-305.

Böttcher, M.E., and Gehlken, P.-L., 1995. Characterization of biogenic and inorganic magnesian calcites by FTIR spectroscopy. Terra Abstracts, 7/ $1: 69$.

Böttcher, M.E., Gehlken, P.-L., and Steele, D.F., 1997. Characterization of inorganic and biogenic magnesian calcites by Fourier Transform infrared spectroscopy. Solid State Ionics, 101/103:1379-1385,

Burdett, J.W., Arthur, M.A., and Richardson, M., 1989. A Neogene seawater sulfur isotope age curve from calcareous pelagic microfossils. Earth Planet. Sci. Lett., 94:189-198.

Claypool, G.E., Holser, W.T., Kaplan, I.R., Sakai, H., and Zak, I., 1980. The age curves of sulfur and oxygen isotopes in marine sulfate and their mutual interpretation. Chem. Geol., 28:199-260. 
Craig, H., 1957. Isotopic standards for carbon and oxygen and correction factors for mass-spectrometric analysis of carbon dioxide. Geochim. Cosmochim. Acta, 12:133-149.

De Lange, G.J., Boelrijk, N.A.I.M., Catalano, G., Corselli, C., Klinkhammer, G.P., Middelburg, J.J., Mueller, D.W., Ullman, W.J., Van Gaans, P., and Woittiez, J.R.W., 1990. Sulphate-related equilibria in the hypersaline brines of the Tyro and Bannock Basins, eastern Mediterranean. Mar. Chem. 31:89-112.

Emeis, K.-C., Robertson, A.H.F., Richter, C., et al., 1996. Proc. ODP, Init. Repts., 160: College Station, TX (Ocean Drilling Program).

Füchtbauer, H., and Goldschmidt, M., 1955. Beziehungen zwischen Calciumgehalt und Bildungsbedingungen der Dolomite. Geol. Rundsch., 55:29-40.

Golyshev, S.I., Padalko, N.L., and Pechenkin, S.A., 1981. Fractionation of stable oxygen and carbon isotopes in carbonate systems. Geochem. Internat., 10:85-99.

Katz, A., Sass, E., Starinsky, A., and Holland, H.D., 1972. Strontium behavior in the aragonite-calcite transformation: an experimental study at $40^{\circ}-$ $98^{\circ}$. Geochim. Cosmochim. Acta, 36:481-496.

Kharaka, Y.K., Gunter, W.D., Aggarwall, P.K., Perkins, E.H., and DeBraal, J.D., 1988. SOLMINEQ: a computer program for geochemical modelling of water rock interactions. Invest. Rep. Wat. Resour. U.S. Geol. Surv., 884277.

Kretz, R., 1982. A model for the distribution of trace elements between calcite and dolomite. Geochim. Cosmochim. Acta, 46:1979-1981.

Matthews, A., and Katz, A., 1977. Oxygen isotope fraction during the dolomitization of calcium carbonate. Geochim. Cosmochim. Acta, 41:14311438

Morse, J.W., and Mackenzie, F.T., 1990. Geochemistry of Sedimentary Carbonates. Dev. in Sedimentology, 48: Amsterdam (Elsevier).

O’Neil, J.R., Clayton, R.N., and Mayeda, T.K., 1969. Oxygen isotope fractionation in divalent metal carbonates. J. Chem. Phys., 51:5547-5558.
Plummer, L.N., and Busenberg, E., 1982. The solubility of calcite, aragonite and vaterite in $\mathrm{CO}_{2}-\mathrm{H}_{2} \mathrm{O}$ solutions between 0 and $90^{\circ} \mathrm{C}$, and an evaluation of the aqueous model for the system $\mathrm{CaCO}_{3}-\mathrm{CO}_{2}-\mathrm{H}_{2} \mathrm{O}$. Geochim. Cosmochim. Acta, 46:1011-1040.

Romanek, C.S., Grossmann, E.L., and Morse, J.W., 1992. Carbon isotope fractionation in synthetic aragonite and calcite. Geochim. Cosmochim. Acta, 56:419-430.

Rosenbaum, J.M., and Sheppard, S.M.F., 1986. An isotopic study of siderite, dolomite and ankerite at high temperatures. Geochim. Cosmochim. Acta, 50:1147-1150

Stenni, B., and Longinelli, A., 1990. Stable isotope study of water, gypsum and carbonate samples from the Bannock and Tyro Basins, Eastern Mediterranean. Mar. Chem., 31:123-135.

Tennant, C.B., and Berger, R.W., 1957. X-ray determination of dolomite?calcite ratio of a carbonate rock. Am. Mineral., 42:23-29.

Veizer, J., 1983. Trace elements and isotopes in sedimentary carbonates. In Reeder, R.J. (Ed.), Carbonates: Mineralogy and Chemistry: Washington (Mineral. Soc. Am.), 265-300.

Walters, L.J., Claypool, G.E., and Choquette, P.W., 1972. Reaction rates and $\delta^{18} \mathrm{O}$ variation for the carbonate-phosphoric acid preparation method. Geochim. Cosmochim. Acta, 36:129-140.

Wiwchar, B.W., Perkins, E.H., and Gunter, W.D., 1988. Solmineq.88 PC/ Shell, User Manual. Alberta Res. Counc., 1-46.

Zheng, Y.-F., 1997. Oxygen isotope fractionation in carbonate and sulfate minerals. Chem. Geol., 127:177-187.

Date of initial receipt: 17 January 1997

Date of acceptance: 15 May 1997

Ms 160SR-067

Table 3. Stable carbon and oxygen isotope data for the calcite and dolomite fractions, and sulfur isotope data for structurally bond sulfate of selected bulk samples.

\begin{tabular}{|c|c|c|c|c|c|}
\hline $\begin{array}{l}\text { Core, section, } \\
\text { interval }(\mathrm{cm})\end{array}$ & $\begin{array}{l}\text { Calcite } \\
\delta^{13} \mathrm{C} \\
(\% o)\end{array}$ & $\begin{array}{c}\text { Calcite } \\
\delta^{18} \mathrm{O} \\
(\% o)\end{array}$ & $\begin{array}{c}\text { Dolomite } \\
\delta^{13} \mathrm{C} \\
(\% o)\end{array}$ & $\begin{array}{c}\text { Dolomite } \\
\delta^{18} \mathrm{O} \\
(\% o)\end{array}$ & $\begin{array}{c}\text { Sulfate } \\
\delta^{34} \mathrm{~S} \\
(\% \circ)\end{array}$ \\
\hline $4 \mathrm{H}-3,98-100$ & -0.93 & 0.16 & - & - & - \\
\hline $17 X-1,1-3$ & 1.26 & 1.15 & - & - & \\
\hline $19 \mathrm{X}-1,1-3$ & 1.11 & 0.39 & 2.32 & 3.85 & - \\
\hline $21 X-1,5-7$ & - & - & 1.62 & 5.01 & 23.6 \\
\hline $23 \mathrm{X}-1,28-30$ & - & - & 2.07 & 4.96 & 23.5 \\
\hline $24 \mathrm{X}-1,80-82$ & 0.92 & 1.50 & 1.84 & 4.00 & \\
\hline $25 \mathrm{X}-1,57-58$ & & & 2.59 & 5.16 & 23.8 \\
\hline $26 \mathrm{X}-1,115-117$ & 1.21 & 2.00 & & & \\
\hline $27 \mathrm{X}-1,45-47$ & 0.73 & 0.66 & 2.23 & 4.56 & 23.7 \\
\hline
\end{tabular}

Note: $-=$ not determined

Table 4. Compositions of interstitial waters from Hole 965A, and calculated saturation indices with respect to calcite (Cc), ordered dolomite (Do), and disordered dolomite (doDo).

\begin{tabular}{|c|c|c|c|c|c|c|c|c|c|c|c|c|c|c|c|c|c|c|c|c|}
\hline $\begin{array}{l}\text { Core, section, } \\
\text { interval }(\mathrm{cm})\end{array}$ & $\begin{array}{l}\text { Depth } \\
\text { (mbsf) }\end{array}$ & $\mathrm{pH}$ & $\begin{array}{l}\text { Alkalinity } \\
(\mathrm{mM})\end{array}$ & $\begin{array}{l}\text { Salinity } \\
(\mathrm{g} / \mathrm{kg})\end{array}$ & $\begin{array}{c}\mathrm{Ca} \\
(\mathrm{mM})\end{array}$ & $\begin{array}{c}\mathrm{Mg} \\
(\mathrm{mM})\end{array}$ & $\begin{array}{c}\mathrm{Sr} \\
(\mu \mathrm{M})\end{array}$ & $\begin{array}{c}\mathrm{SO}_{4} \\
(\mathrm{mM})\end{array}$ & $\begin{array}{c}\mathrm{Na} \\
(\mathrm{mM})\end{array}$ & $\begin{array}{c}\mathrm{K} \\
(\mathrm{mM})\end{array}$ & $\begin{array}{c}\mathrm{Li} \\
(\mu \mathrm{M})\end{array}$ & $\begin{array}{c}\mathrm{Rb} \\
(\mu \mathrm{M})\end{array}$ & $\begin{array}{l}\mathrm{NH}_{4} \\
(\mu \mathrm{M})\end{array}$ & $\begin{array}{c}\mathrm{H}_{4} \mathrm{SiO}_{4} \\
(\mu \mathrm{M})\end{array}$ & $\begin{array}{c}\mathrm{Cl} \\
(\mathrm{mM})\end{array}$ & $\begin{array}{c}\mathrm{Br} \\
(\mu \mathrm{M})\end{array}$ & $\begin{array}{l}\delta^{34} \mathrm{~S} \\
(\% \circ)\end{array}$ & $\begin{array}{l}\mathrm{SI} \\
\mathrm{Cc}\end{array}$ & $\begin{array}{l}\text { SI } \\
\text { Do }\end{array}$ & $\begin{array}{c}\text { SI } \\
\text { doDo }\end{array}$ \\
\hline $\begin{array}{c}160-965 \mathrm{~A}- \\
2 \mathrm{H}-1\end{array}$ & 6.78 & 7.35 & 2.57 & 38 & 11.9 & 57.3 & 111 & 30.7 & 528 & 11.8 & 38 & 1.72 & 43 & 176 & 608 & 1.0 & 20.9 & -0.4 & 1.2 & -0.5 \\
\hline $3 \mathrm{H}-1$ & 16.28 & 7.41 & 2.76 & 38 & 12.2 & 56.5 & 110 & 30.2 & n.d. & 12.2 & 38 & 1.58 & 29 & 163 & 607 & 1.1 & 21.7 & -0.3 & 1.3 & -0.3 \\
\hline
\end{tabular}

Note: Sulfur isotope data are from Böttcher et al., Chap. 29, this volume. n.d. = not determined. 